\title{
The influence of hydraulic loading on biofilm properties in a subsurface wastewater infiltration system
}

\author{
Liangbo Zhang ${ }^{1,2}$, Jian Yang²* \\ ${ }^{1}$ Henan University of Technology, China \\ School of Chemistry and Chemical Engineering \\ ${ }^{2}$ Tongji University, China \\ College of Environmental Science and Engineering \\ *Corresponding author's e-mail: zlb2863@163.com
}

\begin{abstract}
Keywords: subsurface wastewater infiltration system, biofilms, hydraulic loading, spatial distribution, biofilm properties.

Abstract: In this study, a pilot-scale subsurface wastewater infiltration system (SWIS) was deployed to study landscape water treatment. The goal of the study was to investigate the effects of hydraulic loading on pollutant removal and the spatial distribution of biofilm properties in SWIS. Results showed that the efficiencies of chemical oxygen demand (COD), total nitrogen (TN) and total phosphorus (TP) removal degraded as hydraulic loading increased. Furthermore, quantities of the biofilm properties parameters increased with the hydraulic loading. Polysaccharide and protein levels ranged from 560 to $1110 \mu \mathrm{g} / \mathrm{g}$ filler and 60 to $190 \mu \mathrm{g} / \mathrm{g}$ filler, respectively, at a hydraulic loading of $0.2 \mathrm{~m} / \mathrm{d}$. At a hydraulic loading of $0.4 \mathrm{~m} / \mathrm{d}$, the quantities of polysaccharide and protein ranged from 1200 to $3300 \mu \mathrm{g} / \mathrm{g}$ filler and 80 to $290 \mu \mathrm{g} / \mathrm{g}$ filler, respectively. Biofilm intensity and biofilm activity per unit weight decreased with the increase in hydraulic loading.
\end{abstract}

\section{Introduction}

Rapid urbanization and population growth in China have contributed to environmental pollution, which includes surface water eutrophication. Landscape water, a form of surface water, can beautify the environment, increase humidity, clean the atmosphere, improve a district's local climate, and enhance people's appreciation for the environment. With the rapid economic development of China, nitrogen and phosphorus lead to serious eutrophication of urban landscape waters. Treating this landscape water is critical to both the environment and quality of life.

A subsurface wastewater infiltration system (SWIS) has been used to successfully treat landscape water with low-concentration pollution (Yang et al. 2010, Zhang et al. 2011). A SWIS has many advantages, such as simple construction, low operational and maintenance costs, and simple operation (Avinash et al. 2009, Belinda et al. 2007, Pan et al. 2013). In a SWIS, wastewater is first treated using conventional physico-chemical or biological methods; the water then permeates an aerated unsaturated zone, where it is purified using processes such as filtration, adsorption, chemical reaction, and biodegradation ( $\mathrm{Li}$ et al. 2012).

Afundamental characteristic of a SWIS is that its functionality relies heavily on the metabolism of microorganisms contained within the biofilm. As such, studying the biofilm treatment process and characteristics, such as biofilm weight, activity and spatial distribution, are an important part of SWIS studies and may help improve SWIS structure. Microbial ecology studies broaden knowledge about microbial communities and may help improve SWIS design and performance by providing effective indicators of biofilm function and health.

Lazarova and Manem (1995) reviewed the techniques used to measure biofilm activities and characteristics, and concluded that simple and precise methods to measure bacterial biomass and activity are needed to maximize biofilm benefits.

As the indicators of biofilm development and activity, a range of parameters, such as VSS (volatile suspended solid), viable cells number, protein, polysaccharide, respiration intensity and dehydrogenase activity (electron transport system activity), can be used to describe biofilm weight and activity in SWIS.

To a certain extent, VSS expresses the quantity of the biofilm. Viable cells can be express by viable biomass in biofilm system, which can be quantified using phospholipids extraction and phosphate analysis (Findlay et al. 1989). The physico-chemical properties of carrier surfaces induce bacterial cells to secrete extracellular polymeric substances (EPS), when these cells are deposited onto fillers (Renner and Weibel 2011). EPS are high-molecular-weight molecules consisting of polysaccharides, DNA, proteins, lipids, and humic acids. These molecules are released by microbes and adhere onto the cell surfaces of activated sludge, granular sludge, and biofilms in wastewater treatment plants (Flemming and Wingender 2010). As the main components of EPS, protein and polysaccharides produced by growing bacteria indicate 
biofilm quantity, because the biofilm is essentially represented by an agglomeration of specific microbial cells, EPS and water. Indeed, EPS represents $50-90 \%$ of the biofilm organic carbon (Rajeb et al. 2009); it has also been found that the ratio of protein to polysaccharide indicates biofilm strength (Lazarova et al. 1994, Ragusa et al. 2004).

Respiration intensity represents the metabolism degree of biofilm, and dehydrogenase activity is considered a good measure of microbial oxidative activity in water treatment. As such, the two parameters can be used to measure biofilm activity. Enzymes respond to the intensity and direction of biological activities in biofilm process (Huang et al. 2012), and there is increasing evidence that microbial properties (e.g., microorganism, enzymes, and basal respiration) can serve as potential indicators to support whole system management.

SWIS has the capacity to decompose organic matter, measured as biochemical oxygen demand $\left(\mathrm{BOD}_{5}\right)$ and chemical oxygen demand (COD). Past studies have revealed that operational conditions, including hydraulic loading rate (HLR) and pollutant loading rate (PLR), affect soil treatment system performance (Arve et al. 2006, Dalahmeh et al. 2014, Li et al. 2011). Fluctuating hydraulic and organic loads under peak conditions can temporarily break down the filter system, called an "episodic failure" (Beal et al. 2008). High hydraulic loads increase the infiltration rate, reducing the exchange of mobile water in macropores and retained water in micropores (Boller et al. 1993). Conversely, low hydraulic loads encourage exchange between mobile and retained water, prolonging residence time (Rodgers et al. 2005). An increase in the interaction between organic matter and biofilm stimulates microorganism biological activity (Wilson et al. 2011) and the mineralization rate of organic matter (Wijeyekoon et al. 2004). Under high organic loads, a dense biofilm can develop, restricting substrate movement into the biofilm's interior.

Several studies have been carried out to assess biofilm characteristics of SWIS (Zhang et al. 2011, Pan et al. 2013, Pan et al. 2015), however, the effects of hydraulic loading on pollutant removal efficiencies and SWIS biofilm characteristics are not clear. To fill this gap, this study evaluated the effects of hydraulic loading on pollutant removal and the spatial distribution of biofilm properties in SWIS. This research was designed to further establish the operational mechanism of the SWIS process.

\section{Materials and Methods}

\section{Field site location and filler characteristics}

A $50 \mathrm{~m}^{2}$ pilot SWIS (20 m long, $2.5 \mathrm{~m}$ wide and $1.0 \mathrm{~m}$ deep) was constructed in a village located on Chongming Island, Shanghai City, China. River landscape water was pumped into distributing pipes installed at the bottom of the distributing slot. Treated effluent was collected through collection pipes at the bottom of the pilot system. The surface soil of the SWIS was seeded with rye grass. The system was divided into two parts: a distributing water section and a filler section. The distribution slot was filled with $1-2 \mathrm{~cm}$ gravel pieces; the filler section was filled with sand. Sand characteristics were as follows: $0.3-1 \mathrm{~mm}$ particle size, $2.59 \mathrm{~g} / \mathrm{cm}^{3}$ density, $42 \%$ porosity, and $0.9361 \pm 0.0025 \mathrm{~m}^{2} / \mathrm{g}$ specific surface area. During the experiment, the system was continuously fed with river water at a hydraulic loading of $0.2 \mathrm{~m} / \mathrm{d}$ and $0.4 \mathrm{~m} / \mathrm{d}$.

\section{Influent quality}

Table 1 lists the quality of the study's influent landscape water, including hydrochemistry parameters such as $\mathrm{pH}$, dissolved oxygen (DO), oxidation-reduction potential (ORP) and water temperature $(\mathrm{T})$. Influent concentration fluctuated during the operation period based on local rainfall.

\section{Sampling}

To test biofilm build-up over time, filler particles (sand) were removed from the system using a sampler and were placed into small pre-weighed tubes. Sixteen sampling spots were installed in a longitudinal section of the system. The average value of three times was used for each assay. Filler samples used to measure several parameters were removed from refrigerated sample containers and frozen at $-20^{\circ} \mathrm{C}$ until analyzed.

\section{Water quality parameters}

A MERCK Spectroquant TR420/NOVA60 COD (Germany) meter was used for chemical oxygen demand (COD) analysis; turbidity was measured using a $\mathrm{HACH}$ (America) 2100 Turbidimeter. Each sample analysis was repeated three times.

\section{Quantization of biofilm components Aqueous rate}

A certain amount of filler was weighed using an electro-balance, oven-dried for 2 hours at $105^{\circ} \mathrm{C}$, and then reweighed. The aqueous rate is expressed using Equation (1), where $W$ is the filler mass after being dried, and $W_{0}$ represents the mass before being dried.

$$
\text { Aqueous rate }=\left(W_{0}-W\right) / W_{0}
$$

\section{VSS}

To determine VSS, the same dried filler used to determine the aqueous rate was converted to ash, by placing the filler in a muffle furnace for 3 hours at $605^{\circ} \mathrm{C}$. The resulting ash was then reweighed; the difference between the mass of the dried filler and the mass of the ash is the VSS value.

Table 1. Influent quality

\begin{tabular}{|c|c|c|c|c|c|c|c|}
\hline Items & $\mathrm{T}\left({ }^{\circ} \mathrm{C}\right)$ & $\mathrm{pH}$ value & $\mathrm{DO}(\mathrm{mg} / \mathrm{L})$ & $\mathrm{COD}(\mathrm{mg} / \mathrm{L})$ & $\begin{array}{c}\text { Turbidity } \\
(\mathrm{NTU})\end{array}$ & $\mathrm{TP}(\mathrm{mg} / \mathrm{L})$ & $\mathrm{TN}(\mathrm{mg} / \mathrm{L})$ \\
\hline Range & $1.0-31.0$ & $7.5-8.2$ & $4.8-9.2$ & $14.3-79.0$ & $2.73-10.3$ & $0.06-0.97$ & $1.14-15.0$ \\
\hline Average & 18.8 & 7.8 & 6.9 & 49 & 5.70 & 0.43 & 6.23 \\
\hline
\end{tabular}




\section{Respiration intensity}

Respiration intensity was measured using an alkali absorption method (ISO 16072-2002, Germany standard).

\section{Viable cells}

Viable cells value is expressed as the quantity of phospholipids. Phospholipid extraction and phosphate release from phospholipids was conducted using the method of Findlay et al. (1989). Nanomole phosphate concentrations released from phospholipids were determined using the method of Shatton et al (1983). Phosphate concentration was then correlated to viable biomass using the following conversion factor: $1 \mathrm{nmol}$ phosphate from phospholipid is proportional to $3.4 \times 10^{7}$ cells (based on Findlay et al. (1989)).

\section{Protein and polysaccharides}

Microbes often aggregate to form biofilms, fabricating a network of cells and extracellular polymeric substances (EPS) (Lazarova and Manem 1995). As noted previously, EPS includes a rich matrix of biopolymers, with polysaccharides and proteins as the main two components. The EPS extraction method for this study was modified from the method of Liu and Fang (2002). Filler particles were prepared in a centrifuge tube suspension, with $15 \mathrm{~mL}$ of added sterile deionized water. Next, $18 \mu \mathrm{L}$ formaldehyde $(37 \%)$ was added into the suspension and then left to rest for $1 \mathrm{~h}$ at $4^{\circ} \mathrm{C}$, followed by $1.5 \mathrm{~mL} \mathrm{NaOH}(1 \mathrm{~mol} / \mathrm{L})$ for another $3 \mathrm{~h}$ at $4^{\circ} \mathrm{C}$. The suspension was then centrifuged $\left(13,200 \times \mathrm{g}, 20 \mathrm{~min}, 4^{\circ} \mathrm{C}\right)$; the extracted supernatant was analyzed for EPS content. Polysaccharide concentrations were quantified using a phenol-sulfuric acid method, using glucose as a standard (Dubois et al. 1956). Protein concentrations were determined using the Folin-Phenol method and a UV-vis spectrophotometer (Jasco V-550, Japan) at a wavelength of $490 \mathrm{~nm}$ for polysaccharide, and a wavelength of $500 \mathrm{~nm}$ for protein.

The phenol-sulfuric acid measurement was developed by Liu et al. (1973). The polysaccharide content of biofilm was quantified using Ragusa et al. (1994). Each filler particle was removed from the system and placed in glass reaction tubes of the same size. Next, $1 \mathrm{~mL}$ distilled water and $1 \mathrm{~mL}$ of $5 \%$ phenol were added into each tube, and all tubes were placed in a vortex mixer for 30 seconds to obtain a uniform mixture. Concentrated sulfuric acid $(5 \mathrm{~mL})$ was then added to each tube, while mixing in the vortex mixer continued. Tubes were cooled and the adsorption was measured at $485 \mathrm{~nm}$. Glucose was used to construct standard curves for polysaccharide concentration.

\section{Activity measurements}

To measure activity, a $2 \mathrm{~mL}$ suspended biofilm solution was prepared, an appropriate volume of $0.5 \%(\mathrm{w} / \mathrm{v})$ 2,3,5-tripheyl tetrazolium chloride (TTC) in $0.5 \mathrm{M}$ Tris- $\mathrm{HCl}$ buffer (initial $\mathrm{pH}$ 7.6) was added, and the sample was incubated at $37 \pm 1^{\circ} \mathrm{C}$ for $10 \mathrm{~h}$. Triphenylformazan (reduction production of TTC) was extracted using $25 \mathrm{~mL}$ methanol and measured spectrophotometrically at $485 \mathrm{~nm}$. Results were compared against a control sample of methanol extract of filler without TTC.

\section{Data analysis}

The spatial distributions of several biofilm property parameters isolines were generated using Surfer 8.0. Statistical analyses, including Pearson and Spearman's rank correlations, were calculated using SPSS 14.0, produced by SPSS Incorporation (America). The Pearson correlation coefficient $\left(r_{\mathrm{p}}\right)$ was used to estimate linear correlations. The value of $r_{\mathrm{p}}$ is always between +1 and $-1 ;+1$ indicates a perfect negative correlation; -1 indicates a perfect positive correlation; 0 indicates an absence of relationship. Correlations were considered statistically significant at a $99 \%$ confidence interval $(P<0.01)$.

\section{Results and Discussion}

\section{Overall pilot system performance}

Figure 1 and Table 2 present influent and effluent COD, TN, and TP data under different hydraulic loadings. During the SWIS operation period, the average COD removal efficiency was $39.2-48.6 \%$. The results suggest that COD could be degraded but the removal effect was not high, possibly because of the lower organic concentration and the ratio of $\mathrm{BOD}_{5}$ and $\mathrm{COD}(\mathrm{B} / \mathrm{C})$ value. For total nitrogen, the removal rate was only 9.68-30.0\%, likely because the whole system provided a preferable nitrification environment, but could not create a denitrification environment. As such, TN removal efficiency requires further improvement. The average TP removal efficiency reached $78.6-80.5 \%$.

As Figure 1 and Table 2 show, when hydraulic loading changed from 0.2 to $0.4 \mathrm{~m} / \mathrm{d}$, the average COD effluent concentration changed from 23.5 to $30.4 \mathrm{mg} / \mathrm{L}$, and the average COD removal efficiency degraded from $48.6 \%$ to $39.2 \%$.

The SWIS organic matter degradation process can be described as follows. After being fed, soil adsorbed organic matter. Then, microorganisms gradually converted the adsorbed organic matter into low-molecular-weight matter, easily used by denitrifier and other heterotrophic microbes. Hydraulic detention time shortened as hydraulic loading increased. Increasing the hydraulic loading rate increased the wetted surface, exposing a higher percentage of pore volume to the water. This process was also validated by Sharvelle et al. (2008). The process decreased adsorption potential, shortening the organic reduction period. Furthermore, as hydraulic loading increased, it was easier for fine particulate organic matter to penetrate the system, decreasing particulate organic matter removal. These characteristics are useful in understanding organic matter adsorption and immobility, as previously reported by Michael et al. (2007) and Liang and Liu (2008). Similarly, Aijiao et al. (2008) showed that charcoal filter performance improves as flow rate increases.

When hydraulic loading changed from 0.2 to $0.4 \mathrm{~m} / \mathrm{d}$, the average TN effluent concentration changed from 2.75 to $8.01 \mathrm{mg} / \mathrm{L}$; the average TN removal efficiency degraded from $30.0 \%$ to $9.68 \%$. A similar observation was reported by Li et al. (2012).

In the SWIS, nitrogen is removed through volatilization, adsorption, plant uptake and nitrification-denitrification (IWA 2000, Kadlec et al. 2005). The biofilm growth, indicated by the reduction of organic matter caused by increased hydraulic resistance time, might have caused ammonium assimilation, lowering the effluent's ammonium fraction. Therefore, nitrification coupled with denitrification is the major removal process in the deep SWIS (Belmlont et al. 2004), and the residence time of nitrifying bacteria is a crucial factor for TN removal. However, in this SWIS, the hydraulic detention time (from $1.7 \mathrm{~d}$ to $0.7 \mathrm{~d}$ ) decreased as the hydraulic loading 

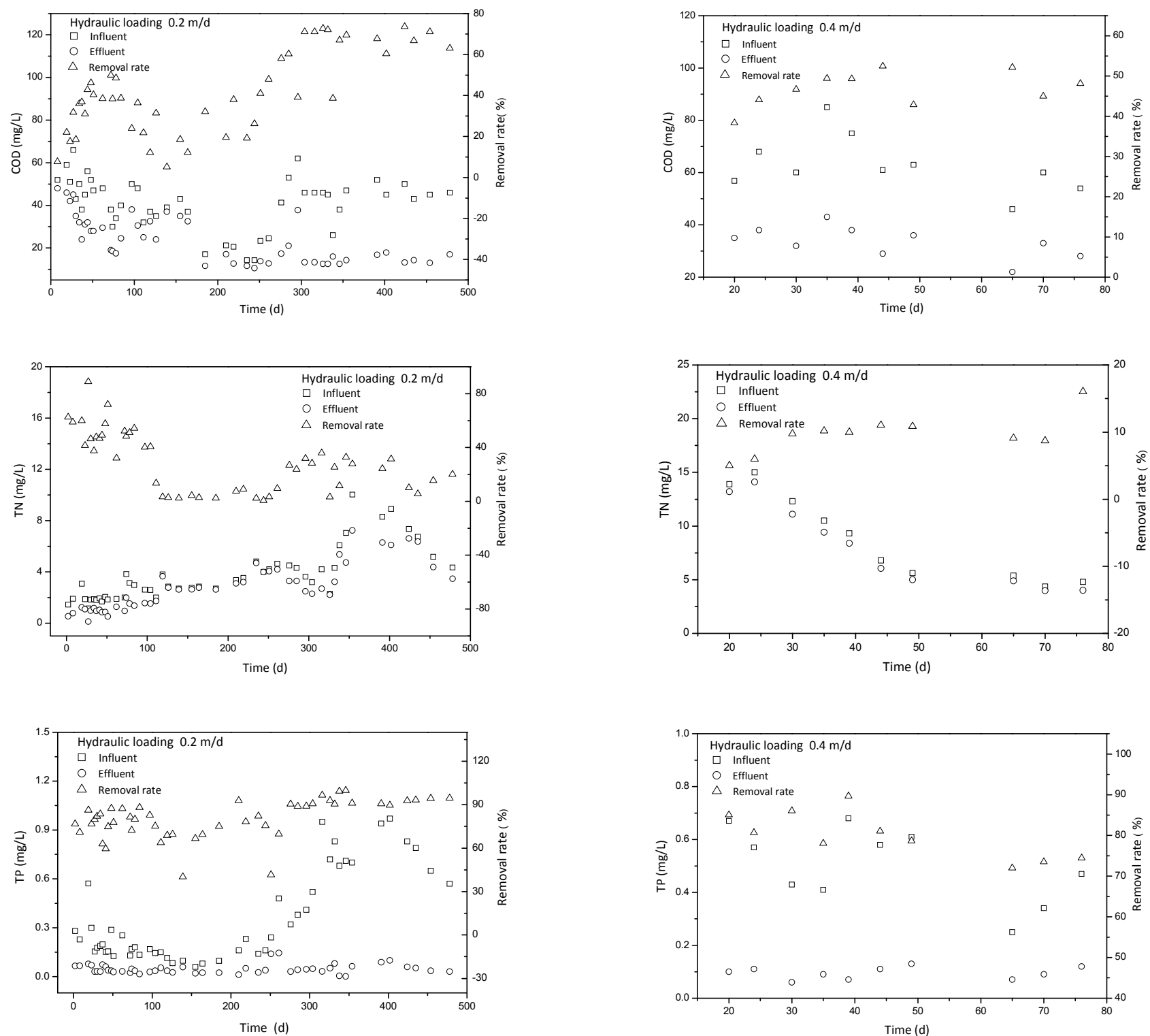

Fig. 1. COD, TN and TP variation under different hydraulic loadings $(0.2$ and $0.4 \mathrm{~m} / \mathrm{d})$

Table 2. Removal efficiencies of COD, TN and TP under different hydraulic loadings ( 0.2 and $0.4 \mathrm{~m} / \mathrm{d})$

\begin{tabular}{|l|c|c|c|c|c|c|c|}
\hline \multirow{3}{*}{ Items } & $\begin{array}{c}\text { Hydraulic } \\
\text { loading } \\
\end{array}$ & \multicolumn{2}{|c|}{ Influent $(\mathrm{mg} / \mathrm{L})$} & \multicolumn{2}{c|}{ Effluent (mg/L) } & \multicolumn{2}{c|}{ Removal (\%) } \\
\cline { 2 - 8 } & $(\mathrm{m} / \mathrm{d})$ & Range & Average & Range & Average & Range & Average \\
\hline \multirow{3}{*}{ COD } & 0.2 & $14.3-59.0$ & 41.2 & $10.5-46.0$ & 23.5 & $12.1-76.9$ & 48.6 \\
\cline { 2 - 9 } & 0.4 & $46.0-79.0$ & 56.9 & $22.0-43.0$ & 30.4 & $38.4-45.5$ & 39.2 \\
\hline \multirow{3}{*}{ TN } & 0.2 & $1.14-10.0$ & 3.66 & $0.13-7.23$ & 2.75 & $2.41-72.0$ & 30.0 \\
\cline { 2 - 9 } & 0.4 & $4.36-15.0$ & 8.79 & $4.02-14.1$ & 8.01 & $6.05-11.0$ & 9.68 \\
\hline \multirow{3}{*}{ TP } & 0.2 & $0.06-0.97$ & 0.36 & $0.02-0.14$ & 0.05 & $40.2-99.8$ & 80.5 \\
\cline { 2 - 9 } & 0.4 & $0.25-0.68$ & 0.50 & $0.06-0.13$ & 0.09 & $73.5-89.6$ & 78.6 \\
\hline
\end{tabular}

increased, and the deviation of average nitrifying bacteria generation time was larger. Therefore, the $\mathrm{TN}$ removal rate decreased as hydraulic detention time increased.

When hydraulic loading changed from 0.2 to $0.4 \mathrm{~m} / \mathrm{d}$, the average TP effluent concentration changed from 0.05 to $0.09 \mathrm{mg} / \mathrm{L}$; the average TP removal efficiency degraded from $80.5 \%$ to $78.6 \%$. TP removal in SWIS was caused by the absorption, interception, surface reaction, and chemistry deposition of organic and inorganic phosphorus. It is assumed that hydraulic detention time decreased with the increase in hydraulic loading. This, in turn, reduced contact time and allowed more efficient phosphate sorption, decreasing the 
opportunity for phosphorus to diffuse from the aqueous phase to the filler surface. Li et al. (2011) drew the similar conclusion that the hydraulic loading rate negatively influenced nitrogen removal in a SWIS.

\section{Spatial distributions of several biofilm property parameters in different hydraulic loadings}

Flow pattern investigations in SWIS systems are indispensable in system optimization, improving the effective capacity ratio. Biofilm comes to life where the water flows, so the SWIS flow pattern can be expressed using the spatial distributions of several parameters, including VSS, respiration intensity, protein, polysaccharide, viable cells number, and dehydrogenase activity. Figures 2-4 and Table 3 present the effects of hydraulic loading on the spatial distributions of SWIS biofilm properties. The first column in Table 3 represents the sampling location (1-16\#). Based on Figures 2-4, the spatial distributions of VSS, viable cells number, polysaccharide, protein, respiration intensity, and dehydrogenase activity were consistent with the aqueous flow rate.

\section{Aqueous rate}

The minimum aqueous rate was in the top left section of the AWIS; the maximum rate was in the bottom right section; and the rate increased gradually from the top left section to the bottom right section. The aqueous rate ranged from $4 \%$ to $34 \%$ when the hydraulic loading was $0.2 \mathrm{~m} / \mathrm{d}$; the rate increased to a range from $7 \%$ to $37 \%$ when the hydraulic loading was $0.4 \mathrm{~m} / \mathrm{d}$.

This regularity is probably caused by the increased interception of water by the fillers as the hydraulic loading increased. In addition, the aqueous rate's spatial distribution was similar under the two hydraulic rates, indicating that water was gradually distributed across the total system under filler capillary action.

The aqueous rate's spatial distribution indicates that the fillers have good permeability, and hydraulic flow characteristics in a SWIS are close to ideal hydraulic fluids (Van et al. 1986). This points a favorable set of hydraulic conditions for SWIS operation.

\section{Biofilm weight parameters}

Biofilm weight can serve as an indicator of biofilm system treatment performance, and biofilm weight correlates to biofilm activity. To assess information about active biofilm quantities in SWIS, a range of parameters, such as VSS, viable cells, polysaccharides, and protein were measured as indicators of biofilm development and activity. Figure 3 shows the effects of hydraulic loading on the spatial distribution of biofilm weight parameters in SWIS. Figure 3 suggests that the distribution regularities of VSS, viable cells number, polysaccharide, and protein in SWIS were consistent with the aqueous rate, as their isolines show the banded distribution.

The minimum VSS and viable cells number were observed in the top left section of the system; the maximum levels were in the bottom right section (Fig. 3 and Table 3). VSS and viable cells levels ranged from 3.8 to $9.0 \mathrm{mg} / \mathrm{g}$ filler and 38 to $98 \mathrm{P} / \mathrm{g}$ filler, respectively, at a hydraulic loading of $0.2 \mathrm{~m} / \mathrm{d}$. At a hydraulic loading of $0.4 \mathrm{~m} / \mathrm{d}$, the VSS and viable number ranged from 7.0 to $17.2 \mathrm{mg} / \mathrm{g}$ filler and 65 to $140 \mathrm{P} / \mathrm{g}$ filler, respectively.

The minimum polysaccharide and protein levels were observed in the top left section of the system; the maximum levels were in the bottom right section (Fig. 3 and Table 3). Polysaccharide and protein levels ranged from 560 to $1110 \mu \mathrm{g} / \mathrm{g}$ filler and 60 to $190 \mu \mathrm{g} / \mathrm{g}$ filler, respectively, at a hydraulic loading of $0.2 \mathrm{~m} / \mathrm{d}$. At a hydraulic loading of $0.4 \mathrm{~m} / \mathrm{d}$, the quantities of polysaccharide and protein ranged from 1200 to $3300 \mu \mathrm{g} / \mathrm{g}$ filler and 80 to $290 \mu \mathrm{g} / \mathrm{g}$ filler, respectively.

Quantities of VSS, viable number, polysaccharide, and protein clearly increased with the increase in hydraulic loading. This was caused by organic matter accumulation, which resulted in the maximum biofilm weight at the bottom of the system. The larger the aqueous rate, the more the fillers were intercepted by wastewater. As such, the biofilm weight increased with hydraulic loading. Boller et al. (1993) similarly concluded that biofilm becomes thicker and holds more water with increasing hydraulic loading rate.

\section{Biofilm activity}

Respiration and dehydrogenase activity expresses the degradation activity of biofilm organic matter. Figure 4 and Table 3 show the effects of hydraulic loading on spatial distributions of biofilm activity parameters. According to Figure 4, the distribution regularities of respiration intensity
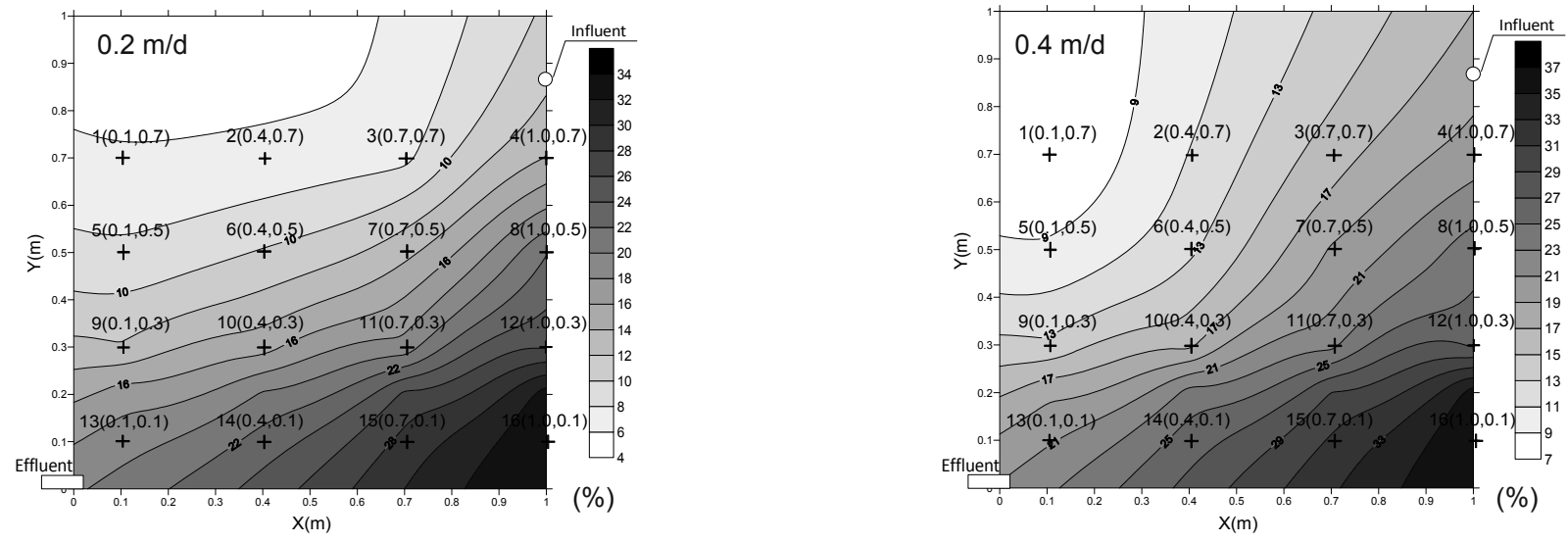

Fig. 2. Aqueous rate spatial distributions at different hydraulic loadings $(0.2$ and $0.4 \mathrm{~m} / \mathrm{d})$ 

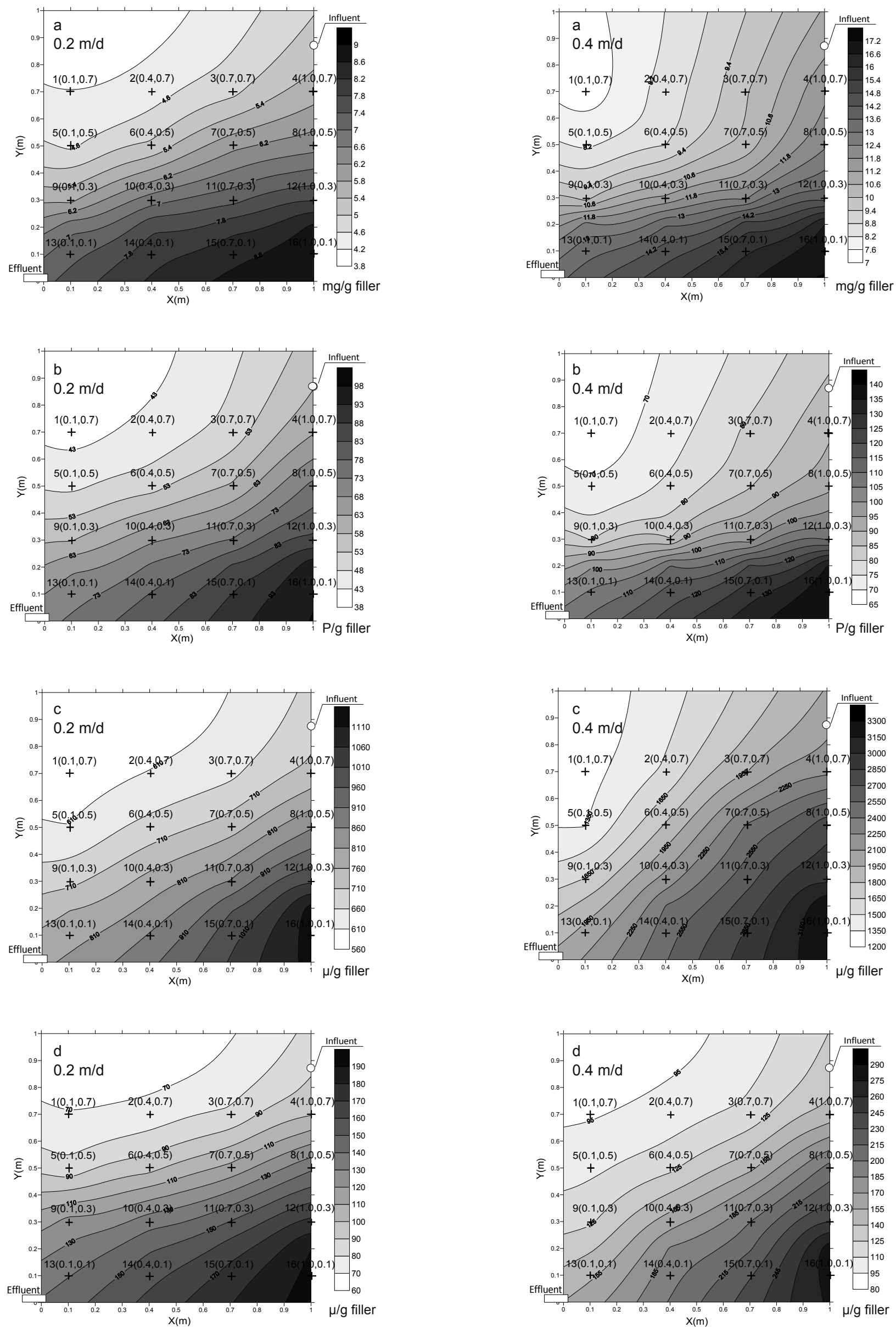

Fig. 3. Spatial distributions of VSS (a), Total viable cell (b), Polysaccharides (c) and Protein (d) at different hydraulic loadings $(0.2$ and $0.4 \mathrm{~m} / \mathrm{d})$ 


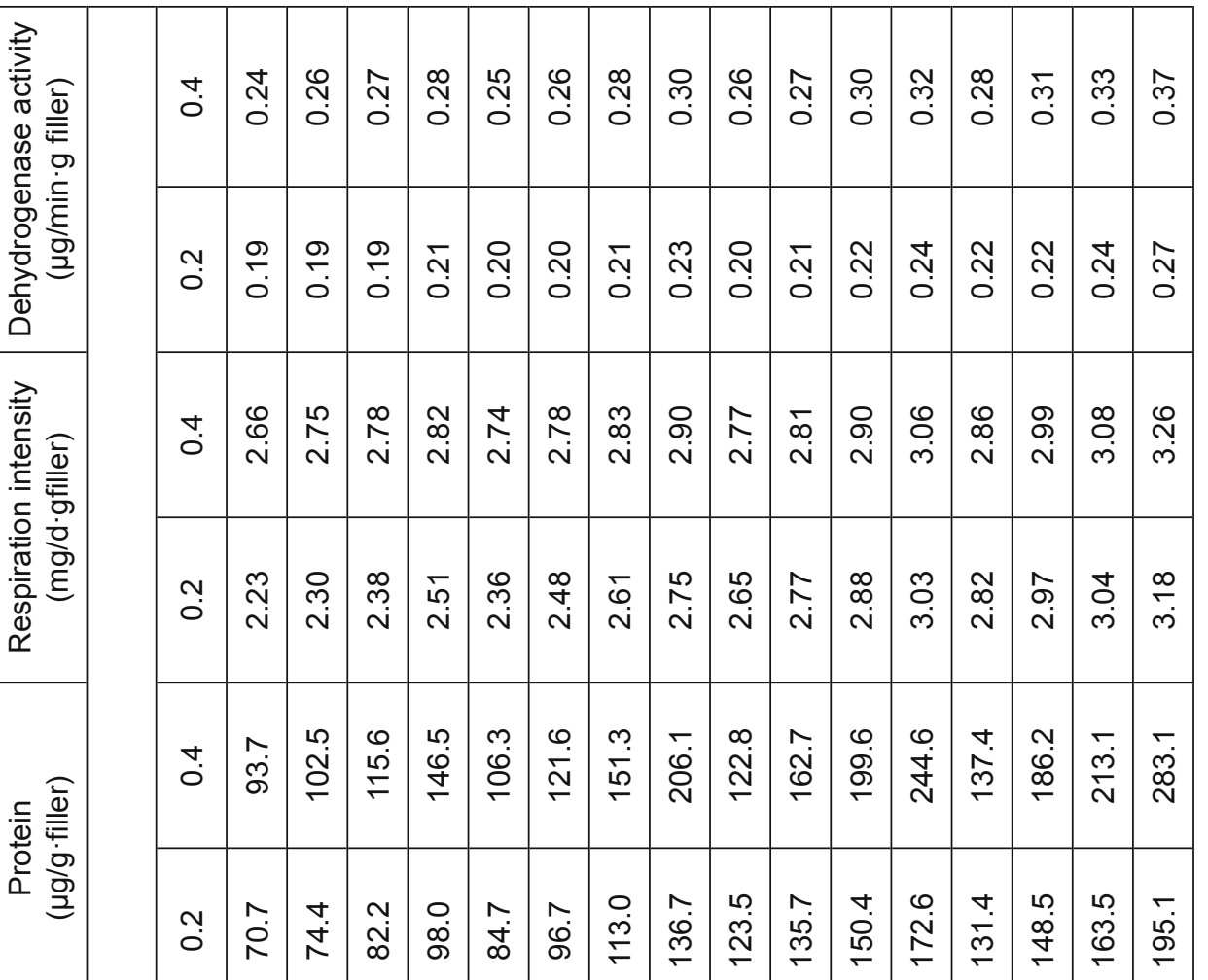

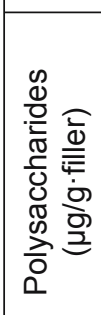

हे

\begin{tabular}{|c|c|c|c|c|c|c|c|c|c|c|c|c|c|c|c|c|}
\hline$\stackrel{+}{+}$ & ભिं & 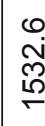 & $\begin{array}{l}\hat{N} \\
\text { J } \\
\text { S }\end{array}$ & 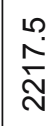 & 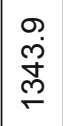 & $\begin{array}{l}0 \\
\dot{0} \\
\stackrel{\infty}{\infty} \\
\stackrel{0}{\circ}\end{array}$ & $\stackrel{m}{\underset{\sim}{\dot{J}}}$ & $\begin{array}{l}0 \\
\stackrel{\sigma}{N} \\
\stackrel{0}{N}\end{array}$ & $\begin{array}{l}m \\
0 \\
\stackrel{0}{ } \\
\varrho\end{array}$ & 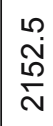 & $\begin{array}{l}0 \\
\underset{N}{ } \\
\tilde{d} \\
\tilde{N}\end{array}$ & 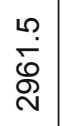 & $\begin{array}{l}\infty \\
\stackrel{0}{\circ} \\
\stackrel{\infty}{\infty} \\
\stackrel{\infty}{\leftarrow}\end{array}$ & $\begin{array}{l}N \\
\stackrel{o}{ } \\
\stackrel{O}{N}\end{array}$ & $\underset{\stackrel{r}{N}}{\stackrel{\sim}{N}}$ & مـ \\
\hline$\stackrel{N}{0}$ & & $\stackrel{\sim}{\sim}$ & 芦 & $\stackrel{9}{0}$ & $\begin{array}{l}0 \\
\text { ָ̇ } \\
0\end{array}$ & $\begin{array}{l}n \\
0 \\
0 \\
0\end{array}$ & 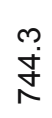 & $\begin{array}{l}\text { @. } \\
\dot{0} \\
\infty\end{array}$ & 定 & \begin{tabular}{|l}
$\infty$ \\
$\infty$ \\
$\infty$ \\
$\sim$
\end{tabular} & \begin{tabular}{|l|l}
10 \\
0 \\
0 \\
0
\end{tabular} & $\begin{array}{l}\stackrel{9}{1} \\
\ddot{8} \\
\stackrel{0}{0}\end{array}$ & $\begin{array}{l}0 \\
\stackrel{N}{R} \\
\stackrel{n}{n}\end{array}$ & $\begin{array}{l}\stackrel{+}{0} \\
\stackrel{\infty}{\infty}\end{array}$ & 今̊ & \\
\hline
\end{tabular}

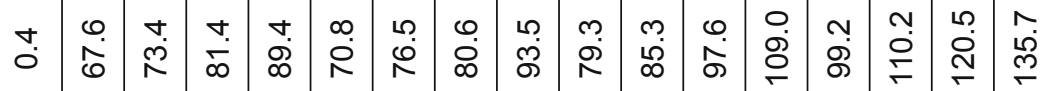

$\circ$ ○

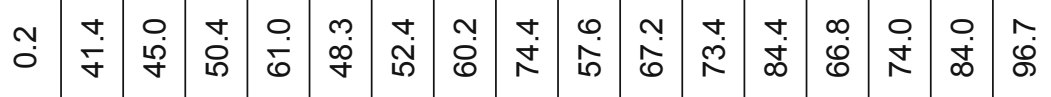

कू

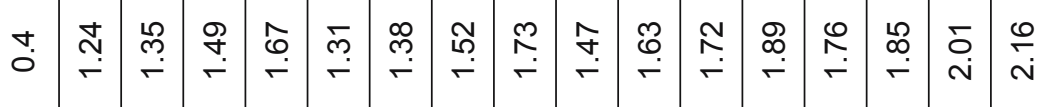

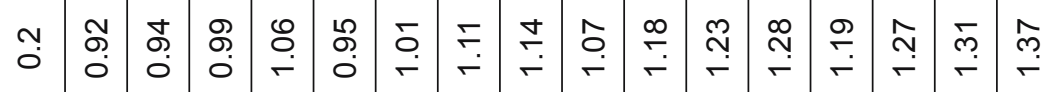

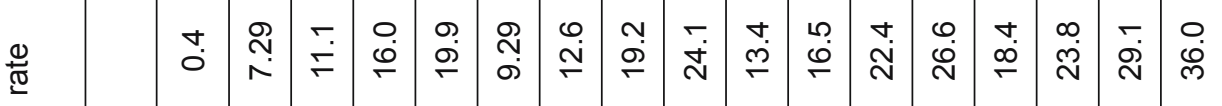

ठำ

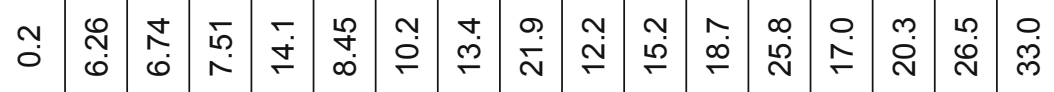

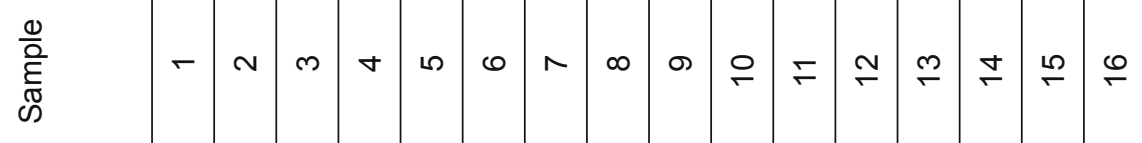


and dehydrogenase activity in SWIS align with the aqueous rate, demonstrated by the isoline band distribution.

The minimum respiration intensity and dehydrogenase activity were observed in the top left section of the system; the maximum was in the bottom right section (Fig. 4 and Table 3 ). These two variables ranged from 2.45 to $3.25 \mathrm{mg} /$ (d.g filler) (respiration) and 0.18 to $0.27 \mu \mathrm{g} /(\mathrm{min} . \mathrm{g}$ filler) (dehydrogenase activity) at a hydraulic loading of $0.2 \mathrm{~m} / \mathrm{d}$. At a hydraulic loading of $0.4 \mathrm{~m} / \mathrm{d}$, the respiration intensity and dehydrogenase activity ranged from 2.65 to $3.29 \mathrm{mg} /$ (d.g filler) and 0.24 to $0.36 \mu \mathrm{g} /(\mathrm{min} . \mathrm{g}$ filler), respectively.

Clearly, respiration intensity and dehydrogenase activity increased with the hydraulic loading increase, likely for the following reasons. Due to higher permeability, the aqueous rate is lower further away from the inlet. Water content in this region is mostly the result of capillary action among the fillers. Because of the lower quantities of small molecule organics carried with interval water among the fillers, the substrate concentration is lower, lowering respiration intensity in this region. In addition, the SWIS environment with the highest respiration intensity not only accumulates nutrient matter and small molecule organics, but also removes numerous contaminants. Biofilm quantity increased with hydraulic loading, so biofilm activity was also enhanced accordingly.

In conclusion, the spatial distributions of VSS, respiration intensity, protein, polysaccharide, viable cells number, and dehydrogenase activity were consistent with the aqueous rate.
This consistency is caused by the accumulation of organic matter, which maximized the levels of several parameters in the bottom of the operating system. Biofilm weight and activity increased with hydraulic loading.

\section{The standard analysis of biofilm parameters}

Table 4 lists specific dehydrogenase levels with respect to protein, polysaccharide, and viable cells number, and the specific protein with respect to polysaccharide and the depth of system. The number represents the sampling spot.

According to Table 4, as filler depth increases, ranging from $30-90 \mathrm{~cm}$ below the system's surface, the ratios of dehydrogenase to protein, dehydrogenase to polysaccharide, dehydrogenase to viable cells number, and protein to polysaccharide all showed a decreasing trend. The decrease in the dehydrogenase to protein ratio was clearest, ranging from $2.43 \times 10^{-3}, 2.34 \times 10^{-3}$ to $1.50 \times 10^{-3}, 1.64 \times 10^{-3}$ at hydraulic loadings of $0.2 \mathrm{~m} / \mathrm{d}$ and $0.4 \mathrm{~m} / \mathrm{d}$, respectively. This indicated that the biofilm activity gradually decreased with biofilm weight along the direction of filled depth, as evidenced by the spatial distribution characteristics.

The protein to polysaccharide ratio, which characterizes biofilm intensity (Lazarova et al. 1994), ranged from $0.13 \times 10^{-3}$, $0.06 \times 10^{-3}$ to $0.18 \times 10^{-3}, 0.09 \times 10^{-3}$ at hydraulic loadings of $0.2 \mathrm{~m} / \mathrm{d}$ and $0.4 \mathrm{~m} / \mathrm{d}$, respectively. This indicates that biofilm intensity increased progressively with the increase of depth. Biofilm activity in the whole system increased with hydraulic loading, however, the biofilm activity per unit of biofilm
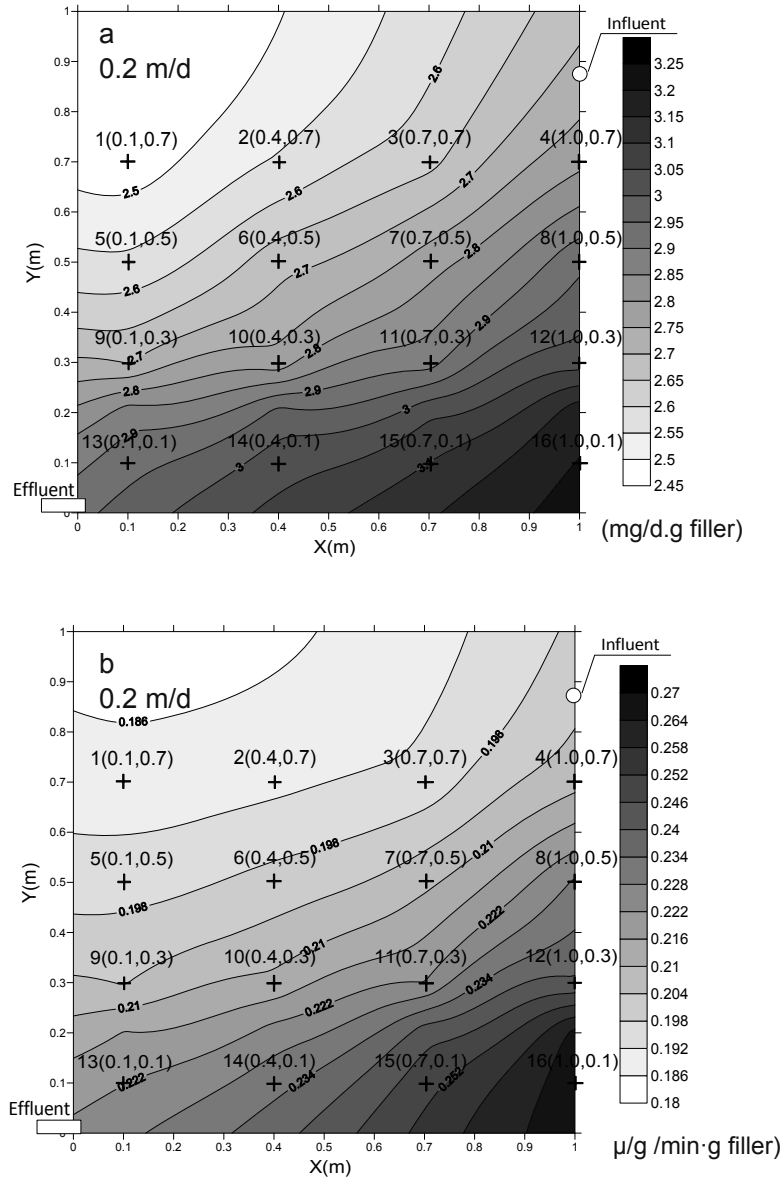
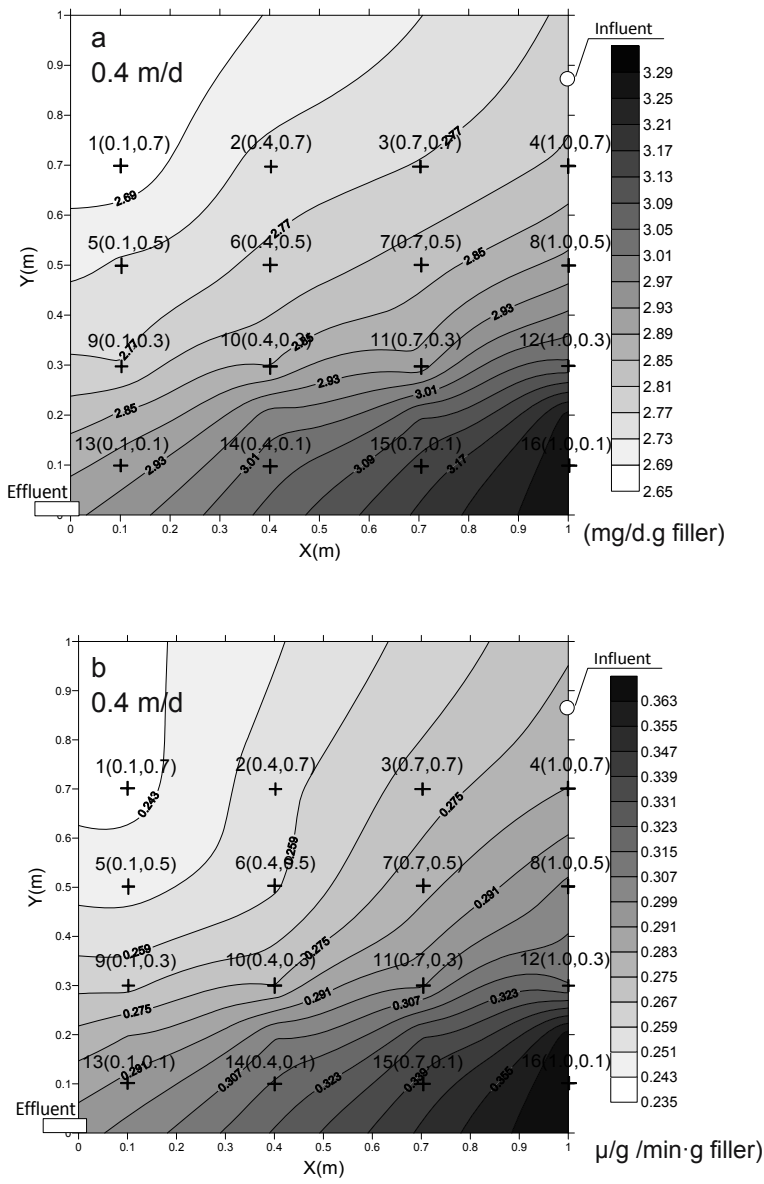

Fig. 4. Spatial distributions of Respiration intensity (a) and Dehydrogenase activity (b) at different hydraulic loadings 
weight decreased. The changes in biofilm properties with depth may be due to the accumulation of organic matter along with water flow in this system. As hydraulic loading increased, dehydrogenase activity was lower than biofilm weight, so the biofilm activity for each unit of biofilm weight could decrease. As for the protein: polysaccharide ratio, it decreased with hydraulic loading, indicating that the biofilm intensity degraded with hydraulic loading. When enhancing the hydraulic loading, the shearing force of water flow to filler biofilm increased, decreasing biofilm intensity accordingly.

\section{The correlation analyses across parameters}

Correlation analyses were used to further investigate parameter relationships (Table 5 presents correlation statistics). Among these parameters, VSS, protein, polysaccharide, viable cells number, respiration intensity, and dehydrogenase activity showed clear relationships. Statistical analysis showed that Pearson's correlation coefficient $\left(r_{\mathrm{p}}\right)$ of VSS, viable cells number, protein, and polysaccharide respiration intensity and dehydrogenase activity exceeded $0.850(P<0.01)$, regardless of whether the hydraulic loading, was $0.2 \mathrm{~m} / \mathrm{d}$ or $0.4 \mathrm{~m} / \mathrm{d}$. All correlations were statistically significant at a $99 \%$ confidence interval $(P<0.01)$ (Table 5). The results are supported by the spatial distributions discussed above (Figs 2-4); organic matter accumulation in the direction of the water flow resulted in similarities across several parameters.

\section{Conclusions}

When hydraulic loading changed from 0.2 to $0.4 \mathrm{~m} / \mathrm{d}$, the COD, $\mathrm{TN}$, and TP removal efficiency all degraded with a similar regularity. The spatial distributions of VSS, respiration intensity, protein, polysaccharide, viable cells number, and dehydrogenase activity were consistent with the aqueous rate. Quantities of VSS, viable number, polysaccharide, protein, respiration intensity, and dehydrogenase activity increased with hydraulic loading. Clear correlations were seen between biofilm activity and biofilm weight; biofilm intensity decreased with the increase in hydraulic loading.

\section{Acknowledgements}

The authors acknowledge the financial support from the Highlevel Talents Foundation of Henan University of Technology (2012BS057) and the Cultivation Project Foundation of Science and Technology Innovation Talents of Henan University of Technology (2014CXRC05) and The Key Scientific Research Projects of Henan Province institution of higher education (16B610004). We thank the State Key Laboratory of Pollution Control and Resources Reuse of China for their support. We also thank the anonymous reviewers for their careful review and valuable suggestions on the manuscript.

Table 4. Variation in parameter ratios with changes in hydraulic loading and depth

\begin{tabular}{|c|c|c|c|c|c|c|c|c|}
\hline \multirow{4}{*}{ The ratio of parameters } & \multicolumn{8}{|c|}{ Depth $(\mathrm{cm})$} \\
\hline & \multicolumn{2}{|c|}{30} & \multicolumn{2}{|c|}{50} & \multicolumn{2}{|c|}{70} & \multicolumn{2}{|c|}{90} \\
\hline & \multicolumn{8}{|c|}{ Hydraulic loading (m/d) } \\
\hline & 0.2 & 0.4 & 0.2 & 0.4 & 0.2 & 0.4 & 0.2 & 0.4 \\
\hline Dehydrogenase / Protein $\left(\times 10^{-3}\right)$ & 2.43 & 2.34 & 1.98 & 1.94 & 1.53 & 1.66 & 1.50 & 1.64 \\
\hline Dehydrogenase / Polysaccharide $\left(\times 10^{-3}\right)$ & 0.32 & 0.15 & 0.29 & 0.14 & 0.27 & 0.13 & 0.26 & 0.12 \\
\hline Dehydrogenase / Viable cell $\times 10^{7}\left(\times 10^{-3}\right)$ & 1.18 & 1.00 & 1.06 & 0.99 & 0.92 & 0.92 & 0.87 & 0.81 \\
\hline Protein / Dehydrogenase $\left(\times 10^{-3}\right)$ & 0.13 & 0.06 & 0.15 & 0.07 & 0.17 & 0.08 & 0.18 & 0.09 \\
\hline
\end{tabular}

Table 5. Pearson Correlation coefficient data of several parameters

\begin{tabular}{|c|c|c|c|c|c|c|c|c|c|c|c|c|c|c|}
\hline \multirow[t]{3}{*}{ Item } & \multicolumn{2}{|c|}{$\begin{array}{l}\text { Aqueous } \\
\text { rate }\end{array}$} & \multicolumn{2}{|c|}{ VSS } & \multicolumn{2}{|c|}{$\begin{array}{c}\text { Respiration } \\
\text { intensity }\end{array}$} & \multicolumn{2}{|c|}{$\begin{array}{c}\text { Viable cell } \\
\text { number }\end{array}$} & \multicolumn{2}{|c|}{ Protein } & \multicolumn{2}{|c|}{ Polysaccharide } & \multicolumn{2}{|c|}{$\begin{array}{c}\text { Dehydrogenase } \\
\text { activity }\end{array}$} \\
\hline & \multicolumn{14}{|c|}{ Hydraulic loading (m/d) } \\
\hline & 0.2 & 0.4 & 0.2 & 0.4 & 0.2 & 0.4 & 0.2 & 0.4 & 0.2 & 0.4 & 0.2 & 0.4 & 0.2 & 0.4 \\
\hline Aqueous rate & 1 & 1 & 0.898 & 0.971 & 0.938 & 0.963 & 0.962 & 0.957 & 0.944 & 0.955 & 0.956 & 0.961 & 0.997 & 0.991 \\
\hline VSS & 0.898 & 0.971 & 1 & 1 & 0.944 & 0.949 & 0.920 & 0.983 & 0.929 & 0.921 & 0.850 & 0.896 & 0.879 & 0.969 \\
\hline $\begin{array}{l}\text { Respiration } \\
\text { intensity }\end{array}$ & 0.938 & 0.963 & 0.944 & 0.949 & 1 & 1 & 0.963 & 0.974 & 0.975 & 0.949 & 0.916 & 0.895 & 0.929 & 0.984 \\
\hline $\begin{array}{l}\text { Viable cell } \\
\text { number }\end{array}$ & 0.962 & 0.957 & 0.920 & 0.983 & 0.963 & 0.974 & 1 & 1 & 0.971 & 0.909 & 0.955 & 0.858 & 0.949 & 0.974 \\
\hline Protein & 0.944 & 0.955 & 0.929 & 0.921 & 0.975 & 0.949 & 0.971 & 0.909 & 1 & 1 & 0.949 & 0.962 & 0.935 & 0.954 \\
\hline Polysaccharide & 0.956 & 0.961 & 0.850 & 0.896 & 0.916 & 0.895 & 0.955 & 0.858 & 0.949 & 0.962 & 1 & 1 & 0.964 & 0.931 \\
\hline $\begin{array}{l}\text { Dehydrogenase } \\
\text { activity }\end{array}$ & 0.997 & 0.991 & 0.879 & 0.969 & 0.929 & 0.984 & 0.949 & 0.974 & 0.935 & 0.954 & 0.964 & 0.931 & 1 & 1 \\
\hline
\end{tabular}




\section{References}

Ai, J.Z., Tao, T., Zhao, H.B. \& Yong, Z. (2008). Effect of charcoal media for the treatment of wastewater in a biological filter, Bioinformatics and Biomedical Engineering, 16-18 May 2008, pp. 3527-3530.

Arve, H., Adam, M.P., Lasse, V., Kinga, Á. \& Petter, D.J. (2006). A high performance compact filter system treating domestic wastewater, Ecological Engineering, 28, pp. 374-379.

Avinash, M.K., Pravin, D.N., Oza, G.H. \& Shankar, H.S. (2009). Treatment of municipal wastewater using laterite-based constructed soil filter, Ecological Engineering, 35, pp.1051-1061.

Beal, C.D., Rassam, D.W., Gardner, E.A., Kirchhof, G. \& Menzies, N.W. (2008). Influence of hydraulic loading and effluent flux on surface surcharging in soil absorption systems, Journal of Hydrologic Engineering, 13, 8, pp. 681-692.

Belinda, E.H., Tim, D.F. \& Ana, D. (2007). Treatment performance of gravel filter medium: implication for design and application of stormwater infiltration systems, Water Research, 41, pp. 2513-2524.

Belmlont, M.A., Cantellano, E., Thompson, S., Williamson, M., Sanchez, A. \& Metcalfe, C.D. (2004). Treatment of domestic wastewater in a pilot scale natural treatment system in central Mexico, Ecological Engineering, 23, pp. 299-311.

Boller, M., Schwager, A. \& Eugster, J.V.M. (1993). Dynamic bahavior of intermittent buried filters, Water Sci. Technol., 28, 10, pp. 99-107.

Dalahmeh, S.S., Pell, M., Hylander, L.D., Lalander, C., Vinnerås, B. \& Jönsson, H. (2014). Effects of changing hydraulic and organic loading rates on pollutant reduction in bark, charcoal and sand filters treating greywater, Journal of Environmental Management, 13, pp. 338-345.

Dubois, M., Gilles, K.A., Hamilton, J.K., Rebers, P.A. \& Smith, F. (1956). Colorimetric method for determination of sugars and related substances, Analytical Chemistry, 28, pp. 350-356.

Findlay, R.H., King, G.M. \& Watling, L. (1989). Efficacy of phospholipid analysis in determining microbial biomass in sediments, Applied and Environmental Microbiology, 55, pp. 2888-2893.

Flemming, H.C. \& Wingender, J. (2010). The biofilm matrix, Nature Reviews Microbiology, 8, pp. 623-633.

Huang, L., Gao, X., Liu, M., Du, G., Guo, J.S. \& Ntakirutimana, T. (2012). Correlation among soil microorganisms, soil enzyme activities, and removal rates of pollutants in three constructed wetlands purifying micro-polluted river water, Ecological Engineering, 46, pp. 98-106.

IWA Special Group on Use of Macrophytes in Water Pollution Control. (2000). Constructed Wetlands for Pollutant Control, Scientific and Technical Report No 8. IWA Publishing, London, England.

Kadlec, R., Ttanner, C., Hally, V. \& Gibbs, M. (2005). Nitrogen spiraling in subsurface flow constructed wetlands implication for treatment repines, Ecological Engineering, 25, pp. 365-371.

Lazarova, V. \& Manem, J. (1995). Biofilm characterization and activity analysis in water and wastewater treatment, Water Research, 29, 10, pp. 2227-2245.

Lazarova, V., Pierzo, V., Fontvielle, D. \& Manem, J. (1994). Integrated approach for biofilm characterisation and biomass activity control, Water Science and Technology, 29, 7, pp. 345-354.

Li, H.B., Li, Y.H., Sun, T.H. \& Wang, X. (2012). The use of a subsurface infiltration system in treating campus sewage under variable loading rate, Ecological Engineering, 38, pp. 105-109.

Li, Y.H., Li, H.B., Sun, T.H. \& Wang, X. (2011). Effects of hydraulic loading rate on pollutants removal by a deep subsurface wastewater infiltration system, Ecological Engineering, 37, No. 9, pp. 1425-1429.
Liang, Z. \& Liu, J.X. (2008). Landfill leachate treatment with a novel process: anaerobic ammonium oxidation (Anammox) combined with soil infiltration system, Journal of Hazardous Materials, 151, pp. 202-212.

Liu, D., Wong, P.T.S. \& Dutka, B.J. (1973). Determination of carbohydrate in lake sediment by a modified phenol-sulfuric acid method, Water Research, 7, pp.741-746.

Liu, H. \& Fang, H.H.P. (2002). Extraction of extracellular polymeric substances (EPS) of sludges, Journal of Biotechnology, 95, pp. 249-256.

Michael, A.U., William, C.B., Marjorie, E.B. \& Song, J. (2007). Nitrogen removal in recirculating sand filter systems with upflow anaerobic components, Journal of Environmental Engineering, 133, pp. 464-470.

Pan, J., Fei, H.X., Song, S.Y., Yuan, F. \& Yu, L. (2015). Effects of intermittent aeration on pollutants removal in subsurface wastewater infiltration system, Bioresource Technology, 191, pp. 327-331.

Pan, J., Yu, L., Li, G.Z., Huang, L.L. \& Jin, H.T. (2013). Characteristics of microbial populations and enzyme activities in non-shunt and shunt subsurface wastewater infiltration systems during nitrogen removal, Ecological Engineering, 61, pp.127-132.

Ragusa, S., de Zoysa, D.S. \& Rengasamy, P. (1994). The effect of microorganisms, salinity and turbidity on hydraulic conductivity of irrigation channel soil, Irrigation Science, 15, pp. 159-166.

Ragusa, S.R., McNevin, D., Qasem, S. \& Mitchellb, C. (2004). Indicators of biofilm development and activity in constructed wetlands microcosms, Water Research, 38, pp. 2865-2873.

Rajeb, A.B., Kallali, H., Aissa, N.B., Bouzaiene, O., Jellali, S., Jedidi, N. \& Hassen, A. (2009). Soil microbial growth and biofilm expansion assessment under wastewater infiltration percolation treatment process: column experiments, Desalination, 246, pp. 514-525.

Renner, L.D. \& Weibel, D.B. (2011). Physicochemical regulation of biofilm formation, MRS Bulletin, 36, pp. 347-355.

Rodgers, M., Healy, M.G. \& Mulqueen, J. (2005). Organic carbon removal and nitrification of high strength wastewaters using stratified sand filters, Water Research, 39, 14, pp. 3279-3286.

Sharvelle, S., McLamore, E. \& Banks, M.K. (2008). Hydrodynamic characteristics in biotrickling filters as affected by packing material and hydraulic loading rate, Journal of Environmental Engineering, 134, 5, pp. 346-352.

Shatton, J.B., Ward, C., Williams, A. \& Weinhouse, S.A. (1983). Microcolorimetric assay of inorganic pyrophosphatase, Analytical Biochemistry, 130, pp. 114-119.

Van, L.H., Wuyts, E. \& Schamp, N. (1986). Elimination of hydrogen sulphide from odorous air by a wood bark biofilter, Water Research, 20, pp.1471-1476.

Wijeyekoon, S., Mino, T., Satoh, H. \& Matsuo, T. (2004). Effects of substrate loading rate on biofilm structure, Water Research, 38, 10, pp. 2479-2488.

Wilson, J., Boutilier, L., Jamieson, R., Havard, P. \& Lake, C. (2011). Effects of hydraulic loading rate and filter length on the performance of lateral flow sand filters for on-site wastewater treatment, Journal of Hydrological Engineering, 16, 8, pp. 639-649.

Yang, J., Zhang, L.B., Wu, Y.F., Wang, Y.Y., Li, C. \& Liu, W. (2010). Treatment and hydraulic performances of the NiiMi process for landscape water, Journal of Zhejiang University-SCIENCE A, 11, 2, pp. 132-142.

Zhang, L.B., Xing, M.Y., Wu, Y.F., Huang, Z.D. \& Yang, J. (2011). Spatial distributions of biofilm properties and flow pattern in NiiMi process, Bioresource Technology, 102, pp.1406-1414. 